\title{
TUBERCULOUS CAVITATION OF THE APICAL SEGMENT OF THE LOWER LOBE
}

\author{
BY \\ H. J. H. HIDDLESTONE AND A. J. TAYLOR \\ From Brompton Hospital, London
}

(RECEIVED FOR PUBLICATION OCTOBER 2, 1953)

The striking difference in incidence of tuberculous disease between the apical segment of the lower lobe and the other lower lobe segments has long been recognized. Kidd (1886) referred to involvement of the latter as "this rare form of the disease," while Fowler (1888) considered the former so frequent a site of disease that he wrote, "In the majority of cases when the physical signs of disease at the apex are sufficiently definite to allow of the diagnosis of phthisis being made, the lower lobe is already affected. No report on the condition of the lungs in a case of apical disease is complete without a distinct statement as to the condition of the "posterior apex' of the lower lobe."

On the other hand, many subsequent investigators failed to recognize this fact (Reisner, 1935). They referred to lower lobe tuberculosis as unusual and irrelevant, and apical lower lobe disease was not recognized as such, the question being confused by inaccurate terminology such as "hilus tuberculosis."

Crofton (1949) published a concise and careful study of apical cavitation of the lower lobe. He concluded that artificial pneumothorax (A.P.) treatment with routine thoracoscopy should be tried. In all forms of pulmonary tuberculosis the pendulum of therapeutic opinion has swung away from "reversible" collapse therapy. Frequently this swing is motivated by enthusiasm without careful scientific appraisal. Gradually the different procedures are being re-assessed. In this paper the problem of treating cavitation of the apex of the lower lobe is re-examined. With Professor Crofton's generous co-operation, the cases studied by him have been reviewed again, together with further cases in patients attending the Brompton Hospital from 1935 to 1950 . An endeavour has been made to discover prognostic criteria and therapeutic indications.

Few authors in the past have clearly differentiated tuberculous disease of the apical segment from that of the other segments of the lower lobe.
The reported incidence of lower lobe lesions has ranged from $0.003 \%$ of sanatorium admissions to $10 \%$ in some series confined to women (Ossen, 1944). In an investigation of cavitated disease, Sweany, Cook, and Kegerreis (1931) reported that $13.7 \%$ of cavities were in the apex of the lower lobe.

The relative frequency of tuberculosis of the apex of the lower lobe has been the subject of several theoretical explanations. That reviewed by Reisner (1935) depends upon the variation in respiratory movement in different areas of the lung. The lower lobes and dorsal portion of the upper lobes are said to be expanded primarily by diaphragmatic movement. The greater portion of the upper lobes and the right middle lobe are acted on by the costal mechanism. The action of the diaphragm is chiefly exerted on the lower and lateral parts of the lower lobes. Thus the apex of the lower lobe lies in an intermediate position poorly served by both mechanisms. This theory also may account for the greater frequency of lower lobe tuberculosis in women, in whom diaphragmatic movement is less effective. As Reisner (1935) expresses it, " the superior boundary of the area ventilated by the diaphragm is lower in females than males."

All reported series show not only the sex difference but also a greater incidence of lower lobe disease on the right side of the chest. Again this might be explicable in terms of lesser movement of the right leaf of the diaphragm, together with the more vertical direction of the right main bronchus. Crofton (1949) also suggests the possibility that some lesions on the left are missed because they are hidden behind the heart in a standard radiograph.

Early writers seemed impressed by the poor prognosis of " basal disease," but their series were small. More recent papers conclude that the prognosis does not differ from disease elsewhere in the lungs, and depends mainly on the type and extent of the disease (Busby, 1939; Gordon, Charr, and 
Sokoloff, 1944 ; Ossen, 1944 ; Crofton, 1949 ; Wayl and Rakower, 1950 ; Bertheau, Peumery, and Coltier, 1951; Müller and Hollatz, 1951).

As far as treatment is concerned there have been varied expressions of opinion. Several authors with large series have been favourably impressed by the value of artificial pneumothorax therapy (Busby, 1939 ; Gordon and others, 1944 ; Ossen, 1944 ; Cohen, 1945 ; Crofton, 1949 ; Macdonald, 1952). On the other hand, Hawkins and Thomas (1946) considered phrenic interruption with pneumoperitoneum a better form of treatment. Other authors frequently combined phrenic interruption with artificial pneumothorax, while some, such as Macdonald (1952), report cases treated by all three procedures. Primary resection has received little mention in the literature. Thus Macdonald (1952) reported only three cases treated by primary resection, and concluded that there is no evidence that this treatment should take priority but that resection will deal successfully with a certain proportion of the minority in which the proven methods of simple collapse treatment fail.

\section{Material and Method of InVestigation}

All radiological reports at the Brompton Hospital from 1935 to 1950 were studied. Where cavitation of the apical segment of the lower lobe was reported, the radiographs were examined if available. In all 198 cases were considered. Of these 36 were diagnosed but not treated at the Brompton Hospital, while in 19 the disease was not adequately localized; these were excluded, leaving a total of 143 . In all these the disease was accurately localized by lateral films or tomography. Adequate radiographs were available in 95 cases. The films of the other cases had been destroyed by fire, but full and reliable reports were available. The notes of the radiologically confirmed cases have been analysed in respect of such factors as age, sex, extent of associated disease, family history, erythrocyte sedimentation rate, sputum state, cavity size and response to therapy. Most cases were treated before the advent of antibacterial therapy and resection, but the series includes a small number of surgically treated cases.

Cavities have been classified as suggested by Foster-Carter, Myers, Goddard, Young, and Benjamin (1952) according to diameter. Those of 1.0 to $1.5 \mathrm{~cm}$. diameter are classified as small, those of 1.5 to $2.5 \mathrm{~cm}$. as medium, and those of more than $2.5 \mathrm{~cm}$. diameter as large. In addition thickness of the wall on the earliest available radiograph has been assessed, and where the surround- ing lung was collapsed or consolidated this has also been noted.

The customary six radiological zones have been used to record the extent of disease: Class 1 , with not more than one zone involved; Class 2, with two or three zones involved; Class 3, with four or more zones involved.

Of the 143 patients, 103 were women. The age at the time of diagnosis ranged from 12 to 55 years. Ninety-five patients had right-sided lesions. Treatment employed included bed rest alone, posture, artificial pneumothorax, phrenic crush and pneumoperitoneum, extrapleural pneumothorax, phrenic crush, oleothorax, thoracoplasty, segmental resection, lobectomy, and pneumonectomy. With the exception of some treated primarily by resection, all patients were followed for a minimum of four years and some as long as 18 years.

\section{Clinical Features}

Sex and Age at Diagnosis. - These two factors are jointly analysed in Table $I$, which sets out the sex incidence in five-year periods between 10 and 55 years.

TABLE I

AGE AND SEX DISTRIBUTION OF 143 CASES OF TUBERCULOUS CAVITATION OF THE APEX OF THE LOWER LOBE

\begin{tabular}{|c|c|c|c|c|c|c|c|c|c|c|}
\hline $\begin{array}{c}\text { Age } \\
\text { Group } \\
\text { (Years) }\end{array}$ & $\begin{array}{c}11- \\
15\end{array}$ & $\begin{array}{l}16- \\
20\end{array}$ & $\begin{array}{c}21- \\
25\end{array}$ & 30 & $\begin{array}{c}31- \\
35\end{array}$ & $\begin{array}{c}36 \\
40\end{array}$ & $\mid \begin{array}{c}41- \\
45\end{array}$ & $\begin{array}{c}46- \\
50\end{array}$ & $\begin{array}{c}51- \\
55\end{array}$ & Total \\
\hline & $\begin{array}{l}3 \\
0\end{array}$ & $\begin{array}{r}18 \\
8\end{array}$ & $\begin{array}{r}30 \\
8\end{array}$ & $\begin{array}{r}21 \\
7\end{array}$ & $\begin{array}{l}9 \\
5\end{array}$ & $\begin{array}{l}9 \\
6\end{array}$ & $\begin{array}{l}9 \\
4\end{array}$ & $\begin{array}{l}3 \\
2\end{array}$ & $\begin{array}{l}1 \\
0\end{array}$ & $\begin{array}{r}103 \\
40\end{array}$ \\
\hline
\end{tabular}

Presenting Symptoms.-While there is nothing characteristic, let alone pathognomonic, about the symptoms, it may be important that low posterior chest pain of a pleuritic or dull character on the same side as the lesion was reported by more than $25 \%$ of the patients. Usually the onset was insidious. "Toxaemic" symptoms such as malaise and fever were present in 30 cases, and "lesional " symptoms such as cough and chest pain in 43 cases.

\section{Radiological Findings}

The location of cavities was studied on standard radiographs, and, when possible, by tomography. On the postero-anteror film most of the cavities were related to the anterior end of the third or fourth ribs. Measurements were made from the centre of the cavity to the lateral chest wall and to the midline. Sixty par cent. of the cavities were found to be midway between these two points, with an even distribution of the remainder on either side. 
Tomographs were available in 39 cases. If its position was not distorted by collapse of any of the segments or by traction from fibrosis of the same lung, the cavity was best seen in the cut which outlined most of the body of the third rib. This usually was the cut $3 \mathrm{~cm}$. from the back, though it naturally varied with the postero-anterior thickness of the patient's chest, and with the tomographic apparatus.

\section{TREATMENT AND RESUltS}

Satisfactory treatment was considered to have been achieved when the following criteria had been satisfied :

(1) Radiological evidence of cavity closure, which was based mainly on standard radiographs. Tomographic evidence was available in 27 cases.

(2) Absence of tubercle bacilli from the sputum: in this respect, the records of some cases are unsatisfactory. When no sputum was available, gastric washings were infrequently examined. In other cases only the results of direct examinations were available.

(3) Absence of symptoms or of evidence of spread of disease.

(4) Return to work.

Where possible the time required for the attainment of these criteria has been analysed as this is obviously an important practical point which in previous reports has largely been ignored.

Some idea of the comparability of groups treated in various ways is provided by the percentage of cases belonging to Class 3 . The therapeutic results may be judged by the percentage returning to work, to measure the economic success of therapy, and the percentage with sputum conversion. These factors are set out in Table II for those cases of the present series, numbering 110 in all, which were treated by A.P., phrenic crush and pneumoperitoneum, thoracoplasty, and resection.

TABLE II

RESULTS OF TREATMENT IN 110 CASES OF TUBERCULOUS CAVITATION OF THE APEX OF THE LOWER LOBE

\begin{tabular}{c|c|c|c|c}
\hline Treatment & $\begin{array}{c}\text { No. of } \\
\text { Patients }\end{array}$ & $\begin{array}{c}\text { No. with } \\
\text { Disease } \\
\text { Involving } \\
\text { Four or More } \\
\text { Radiological } \\
\text { Zones }\end{array}$ & $\begin{array}{c}\text { No. } \\
\text { Returned } \\
\text { to } \\
\text { Work }\end{array}$ & $\begin{array}{c}\text { No. with } \\
\text { Sputum } \\
\text { Converted } \\
\text { to Negative }\end{array}$ \\
\hline $\begin{array}{c}\text { Artificial pneumo- } \\
\text { thorax }\end{array}$ & 64 & $12(18 \cdot 5 \%$ & $44(69 \%)$ & $45(70 \%)$ \\
$\begin{array}{c}\text { Phrenic crush } \\
\text { pneumoperiton- } \\
\text { eum . }\end{array}$ & 23 & $3(13 \%)$ & $13(56 \cdot 5 \%)$ & $13(56 \cdot 5 \%)$ \\
$\begin{array}{c}\text { Thoracoplasty .. } \\
\text { Lobectomy }\end{array}$ & 8 & 3 & 4 & 4 \\
Pneumonectomy & 11 & 0 & 6 & 9 \\
\hline
\end{tabular}

* Only eight of the patients treated by lobectomy were followed for more than one year.
Artificial Pneumothorax.-In 64 cases A.P. was the primary treatment. In a further eight cases it was unsuccessfully attempted. Classification of these cases according to extent of disease showed that 21 belonged to Class 1, 31 to Class 2, and 12 to Class 3. Foster-Carter and others (1952), confirming Wingfield's work, formulated a general rule "that the expectation of survival in pulmonary tuberculosis varies inversely with the radiological extent of the disease." Table III analyses the results of A.P. treatment in the three

TABLE III

RESULTS OF TREATMENT BY ARTIFICIAL PNEUMOTHORAX IN 64 CASES OF TUBERCULOUS CAVITATION IN THE APEX OF THE LOWER LOBE

\begin{tabular}{|c|c|c|c|}
\hline & Class 1 & Class 2 & Class 3 \\
\hline $\begin{array}{l}\text { No. of cases } \\
\text { Cavity closure }\end{array}$ & $\begin{array}{l}21 \\
17(81 \%) \\
18(86 \%) \\
18(86 \%) \\
16 \\
10(48 \%) \\
7(33 \%) \\
0\end{array}$ & $\begin{array}{l}31 \\
21(68 \%) \\
21(68 \%) \\
20(65 \%) \\
31 \cdot 5 \\
20(65 \%) \\
15(48.5 \%) \\
2(6.5 \%)\end{array}$ & $\begin{array}{r}12 \\
6 \\
6 \\
6 \\
22 \\
6 \\
8 \\
4\end{array}$ \\
\hline
\end{tabular}

Minimum follow-up was five years.

classes. Two important factors must be mentioned in considering the percentage of cases requiring further therapy. First, a prophylactic phrenic paralysis was induced in 12 cases at the end of successful pneumothorax therapy. While this must be included as additional therapy, probably it was not of great moment in many cases in the successful outcome of therapy. This factor explains the high proportion of cases requiring further treatment in Class 1 . Secondly, in Class 3 the mortality was high and so fewer patients were available for further therapy.

It must be emphasized that no patient had preliminary antibacterial treatment before pneumothorax induction.

The relation of cavity closure to thickness of the cavity wall and cavity size was studied, and it appeared that the thicker-walled and larger cavities were closed less frequently. Unfortunately too few radiographs were available to make the figures statistically significant.

Although the series of cases treated by artificial pneumothorax is small, it is of interest to contrast the results with those of artificial pneumothorax used in unilateral cavitated disease in general. For this purpose the results are compared with those reported by Foster-Carter and others (1952) for A.P. treatment in general (Table IV). The results are almost identical, confirming that the prognosis 
TABLE IV

COMPARISON OF RESULTS OF ARTIFICIAL PNEUMOTHORAX TREATMENT IN UNILATERAL DISEASE WITH CAVITATION AT ANY SITE AND IN PRESENT SERIES OF CAVITIES OF THE APEX OF THE LOWER LOBE

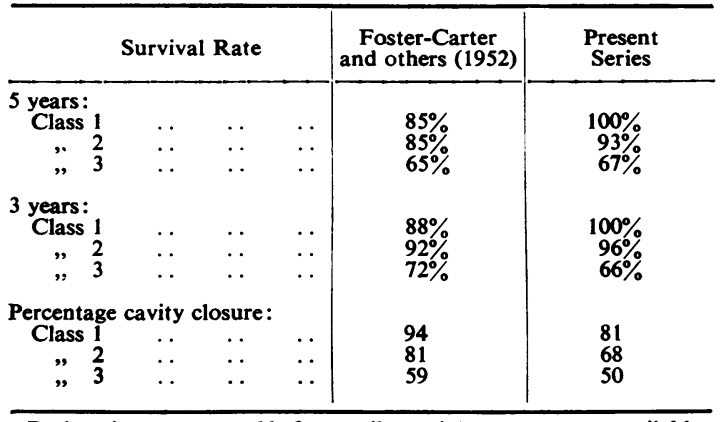

Both series were treated before antibacterial treatment was available.

does not differ from that of disease of comparable extent elsewhere in the lungs.

Finally, it is of interest to compare the results of artificial pneumothorax therapy with those reported by others (Table V), using the same criteria of satisfactory treatment.

TABLE V

COMPARISON OF RESULTS IN PRESENT AND OTHER SERIES OF ARTIFICIAL PNEUMOTHORAX TREATMENT OF CAVITIES IN THE APICAL SEGMENT OF THE LOWER LOBE

\begin{tabular}{|c|c|c|}
\hline & \multicolumn{2}{|c|}{$\begin{array}{c}\text { Percentage of Satisfactory Results * } \\
\text { Obtained } \dagger \text { by }\end{array}$} \\
\hline & $\begin{array}{l}\text { A.P. } \\
\text { Alone }\end{array}$ & $\begin{array}{l}\text { A.P. and Phrenic } \\
\text { Interruption }\end{array}$ \\
\hline $\begin{array}{l}\text { Crofton (1949) } \\
\text { Macdonald (1952) } \\
\text { Present series (Class } 1 \text { and 2). }\end{array}$ & $\begin{array}{r}83(29) \\
100(15) \\
71(35)\end{array}$ & $\begin{array}{l}60(15) \\
77(22) \\
67(15)\end{array}$ \\
\hline
\end{tabular}

* Satisfactory result means closure of cavity and absence of bacilli in sputum.

t Figures in brackets are the total numbers of patients in each group.

Phrenic Crush and Pneumoperitoneum.-In 23 cases phrenic crush and pneumoperitoneum was the primary treatment. The results have been analysed according to the extent of disease in Table VI.

TABLE VI

RESULTS AFTER PHRENIC CRUSH AND PNEUMOPERITONEUM IN 23 CASES OF TUBERCULOUS CAVITATION IN THE APEX OF THE LOWER LOBE

\begin{tabular}{|c|c|c|c|c|}
\hline & & Class 1 & Class 2 & Class 3 \\
\hline $\begin{array}{l}\text { No. of cases } \\
\text { Cavity closure . } \\
\text { Sputum conversion } \\
\text { Returning to work } \\
\text { Average time before }\end{array}$ & $\begin{array}{cc}\ldots & \cdots \\
\cdots & \cdots \\
\cdots & \cdots \\
\text { e returning }\end{array}$ & $\begin{array}{l}\mathbf{4} \\
\mathbf{3} \\
\mathbf{3} \\
\mathbf{3}\end{array}$ & $\begin{array}{r}16 \\
9 \\
9 \\
10\end{array}$ & $\begin{array}{l}3 \\
1 \\
1 \\
0\end{array}$ \\
\hline $\begin{array}{l}\text { to work } \\
\text { Complications } . \\
\text { No. requiring further } \\
\text { Mortality }\end{array}$ & $\begin{array}{cc}\cdots & \cdots \\
\text { treatment } \\
\ldots\end{array}$ & $\begin{array}{l}21 \\
2 \\
2 \\
0\end{array}$ & $\begin{array}{l}29 \cdot 5 \mathrm{mths} \\
12 \\
7 \\
0\end{array}$ & $\begin{array}{l}-3 \\
3 \\
1\end{array}$ \\
\hline
\end{tabular}

Once again an inverse relationship was found to exist between cavity size and cavity wall thickness and frequency of cavity closure.

Phrenic Crush Alone.-This was used in only two cases, both of which were in Class 3, and in neither case did it appear to affect the course of the disease.

Postural Dependence Therapy.-This was used in three cases, in all of which the size of cavity was reduced, but further treatment was required to close it.

Bed Rest Alone.-This was used in six cases, four of which were in Class 3 and two in Class 2. In four cases it was employed because active measures were refused by the patient. In only one (Class 2) patient did the cavity close, after nine months' bed rest, and this patient became sputum negative and returned to full-time active employment.

Extrapleural Pneumothorax.-This was used in three cases, two in Class 2 and one in Class 3. In one patient it produced an excellent result ; one patient died after developing an empyema, and one had a spread of disease in the opposite lung, subsequently controlled by an artificial pneumothorax.

THORACOPLASTY.-The results obtained by thoracoplasty are summarized in Table VII. Eight

TABLE VII

RESULTS AFTER THORACOPLASTY IN EIGHT CASES OF TUBERCULOUS CAVITATION IN THE APEX OF THE LOWER LOBE

\begin{tabular}{|c|c|c|c|c|c|c|}
\hline No. & $\begin{array}{c}\text { No. of } \\
\text { Ribs } \\
\text { Resected }\end{array}$ & $\begin{array}{l}\text { Cavity } \\
\text { Clo- } \\
\text { sure }\end{array}$ & $\begin{array}{c}\text { Sputum } \\
\text { Con- } \\
\text { version }\end{array}$ & $\begin{array}{c}\text { Return } \\
\text { to } \\
\text { Work }\end{array}$ & Complications & $\begin{array}{c}\text { Further } \\
\text { Treatment }\end{array}$ \\
\hline $\begin{array}{l}1 \\
2\end{array}$ & $\begin{array}{l}8 \\
7\end{array}$ & $\begin{array}{c}\text { Yes } \\
0\end{array}$ & $\begin{array}{c}\text { Yes } \\
0\end{array}$ & $14 \mathrm{mths}$ & $\begin{array}{l}\text { Nil } \\
\text { Post-opera- } \\
\text { tive death } \\
\text { paradoxical } \\
\text { respiration }\end{array}$ & Nil \\
\hline $\begin{array}{l}3 \\
4\end{array}$ & $\begin{array}{l}7 \\
8\end{array}$ & $\begin{array}{c}\text { Yes } \\
0\end{array}$ & $\begin{array}{c}\text { Yes } \\
0\end{array}$ & $190 "$ & $\begin{array}{l}\text { Nil } \\
\text { Unclosed } \\
\text { cavity }\end{array}$ & $\begin{array}{c}\text { Nil } \\
, "\end{array}$ \\
\hline 5 & 8 & $\mathbf{0}$ & $\mathbf{0}$ & $\mathbf{0}$ & Spread & Chemo- \\
\hline 6 & 7 & $\mathbf{0}$ & $\mathbf{0}$ & 0 & Unclosed & Lobec- \\
\hline $\begin{array}{l}7 \\
8\end{array}$ & $\begin{array}{l}8 \\
7\end{array}$ & $\begin{array}{c}\text { Yes } \\
,\end{array}$ & $\begin{array}{c}\text { Yes } \\
",\end{array}$ & $\begin{array}{l}20 ", \\
13 \text { ", }\end{array}$ & Nil & Nil \\
\hline
\end{tabular}

patients were treated in this way, in four of whom the disease was adequately controlled. Five of the cases were in Class 2 and three in Class 3. All the latter were unsatisfactory.

RESECTION.-Only cases in which resection was primary therapy are considered here. It must be emphasized that these cases differ from those in 
the previously mentioned treatment groups in that they all had preliminary chemotherapy.

Lobectomy was used in 11 cases, which are summarized in Table VIII. This series is small. The period of follow-up is as yet inadequate ; however, Geake and Young (1953) have shown that where disease spreads after resection it usually does so within 12 months of operation. Probably the most noteworthy point is that those patients who have returned to work did so at an average interval after operation of approximately 11 months.

Primary segmental resection was performed in two cases. In one, the result was excellent and the patient returned to work in 14 months. In the second, there was post-operative segmental collapse of the posterior basal segment of the lower lobe. Subsequently a lower lobectomy was performed with an excellent result and the patient was back at work two years after the lobectomy. In both cases the patients belonged to Class 3 .

Pneumonectomy was performed in four cases, all of Class 2, and results are summarized in Table VIII.

SECONDARY Resection.-This description applies to those cases in which the primary treatment was unsuccessful and the patient subsequently had a resection. This was used in 10 cases and the results are summarized in Table IX.

TABLE VIII

RESULTS AFTER LOBECTOMY AND PNEUMONECTOMY IN 15 CASES OF TUBERCULOUS CAVITATION IN THE APEX OF THE LOWER LOBE

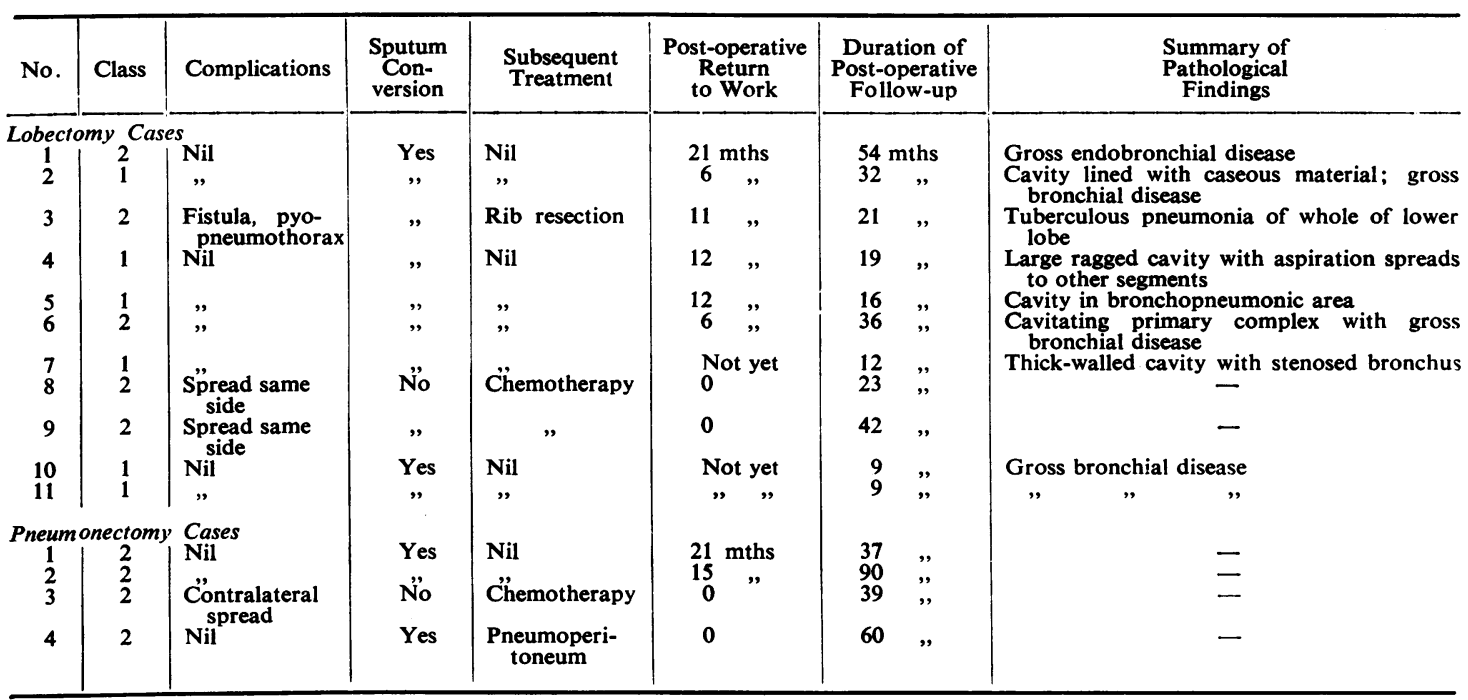

TABLE IX

RESULTS AFTER SECONDARY RESECTION IN 10 CASES OF TUBERCULOUS CAVITATION IN THE APEX OF THE LOWER LOBE

\begin{tabular}{|c|c|c|c|c|c|c|c|c|c|}
\hline \multirow{3}{*}{ No. } & \multirow{3}{*}{ Class } & \multirow{2}{*}{\multicolumn{3}{|c|}{ Primary Treatment }} & \multirow{3}{*}{$\begin{array}{l}\text { Secondary } \\
\text { Treatment }\end{array}$} & \multicolumn{4}{|c|}{ Post-operative Course } \\
\hline & & & & & & \multirow{2}{*}{ Complications } & \multirow{2}{*}{$\begin{array}{l}\text { Sputum } \\
\text { Conver- } \\
\text { sion }\end{array}$} & \multirow{2}{*}{$\begin{array}{l}\text { Time of } \\
\text { Return } \\
\text { to Work } \\
\text { (Months) }\end{array}$} & \multirow{2}{*}{$\begin{array}{l}\text { Duration } \\
\text { of } \\
\text { Follow-up } \\
\text { (Months) }\end{array}$} \\
\hline & & Type & \multicolumn{2}{|c|}{ Duration } & & & & & \\
\hline 1 & 2 & \multirow{2}{*}{$\begin{array}{l}\text { Phrenic and chemotherapy } \\
\text { Artificial pneumothorax } \\
\text { Pneumoperitemeum } \\
\text { Postural treatment and phrenic } \\
\text { Phrenic and pneumoperitoneum }\end{array}$} & \multicolumn{2}{|c|}{13 mths } & \multirow{3}{*}{$\begin{array}{l}\text { Lobectomy } \\
\text { Pneumonectomy } \\
\text { Lobectomy } \\
\text { Pneumonectomy } \\
\text { Lobectomy } \\
\text { " } \\
\text { Pneumonectomy }\end{array}$} & \multirow{3}{*}{$\begin{array}{l}\text { Broncho-pleural } \\
\text { fistula } \\
\text { Nil } \\
\text { " } \\
\text { Broncho-pleural } \\
\text { fistula } \\
\text { Nil } \\
\text { " } \\
\text { " }\end{array}$} & Yes & 13 & 25 \\
\hline $\begin{array}{l}2 \\
3 \\
4 \\
5\end{array}$ & $\begin{array}{l}\mathbf{2} \\
\mathbf{2} \\
\mathbf{2} \\
\mathbf{2}\end{array}$ & & $\begin{array}{r}10 \\
6 \\
24 \\
7\end{array}$ & ", & & & ", & $\begin{array}{l}\overline{15} \\
13 \\
30\end{array}$ & $\begin{array}{l}10 \\
21 \\
25 \\
72\end{array}$ \\
\hline $\begin{array}{r}6 \\
7 \\
8 \\
9 \\
10\end{array}$ & $\begin{array}{l}\mathbf{1} \\
\mathbf{2} \\
\mathbf{2} \\
\mathbf{3} \\
\mathbf{2}\end{array}$ & 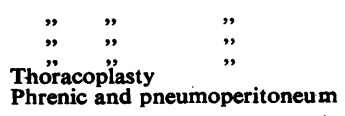 & $\begin{array}{r}26 \\
49 \\
54 \\
84 \\
4\end{array}$ & $\begin{array}{l}\text { ”, } \\
\text { ”, }\end{array}$ & & & $\begin{array}{l}\text { " } \\
\text { No } \\
\text { Yes }\end{array}$ & $\begin{array}{l}10 \\
=\end{array}$ & $\begin{array}{r}57 \\
4 \\
18 \\
6 \\
12\end{array}$ \\
\hline
\end{tabular}




\section{SUMMARY}

The case-histories of 143 patients with tuberculous cavities in the apical segment of the lower lobe of the lung were studied with special reference to the problem of treatment. Such cavities were found to occur more frequently in the right lung and in women.

Low chest pain was found to have occurred in over $25 \%$ of cases, and may be a symptom of some localizing value.

While the length of the follow-up of cases treated by different methods varied, artificial pneumothorax appears to have given the most satisfactory results, even without preliminary antibacterial treatment.

However, the results were equalled in a smaller number of cases, treated by resection after preliminary antibacterial treatment, but followed for a shorter time.
We wish to thank Dr. F. H. Young, who suggested this investigation and has given much helpful criticism.

\section{REFERENCES}

Bertheau, M., Peumery, J. J., and Coltier, B. (1951). Presse méd. , 59,1005

Busby, L. F. (1939). Amer. Rev. Tuberc., 40, 692.

Cohen, R. C. (1945). Brit. med. J., 1, 662.

Crofton, J. (1949). Thorax, 4, 96.

Foster-Carter, A. F., Myers, M., Goddard, D. L. H., Young, F. H., and Benjamin, B. (1952). Brompton Hosp. Rep., 21, 3

Fower, J. K. (1888). The Localisation of the Lesions of Phthisis. Churchill, London.

Geake, M. R., and Young, F. H. (1953). Thorax, 8, 104.

Gordon, B. L., Charr, R., and Sokoloff, M. J. (1944). Amer. Rev. Tuberc., 49, 432

Hawkins, F. S., and Thomas, G. O. (1946). Tubercle, 27, 82.

Kidd, P. (1886). Lancet, 2, 615, 665.

Macdonald, A. W. B. (1952). Tubercle, 33, 194.

Müller, E., and Hollatz, G. (1951). Beitr. Klin. Tuberk., 105, 446.

Ossen, E. Z. (1944). New Engl. J. Med., 230, 693.

Reisner, D. (1935). Arch. intern. Med., 56, 258.

Sweany, H. C., Cook, C. E., and Kegerreis, R. (1931). Amer. Rev. Tuberc., 24, 558 .

Wayl, R., and Rakower, J. (1950). Harefuah (Hebrew ed.), 39, 117. English summary, p. 120. 